\title{
Notes on Eopsis beaumonti BenSON 1959 (Hymenoptera, Tenthredinidae)
}

\author{
With 3 figures \\ KAREL Beneš ${ }^{1}$ \\ ${ }^{1}$ Kreuzmannova 14, 31800 Plzeň, Czech Republic. - beneskarel@seznam.cz \\ Published on 2015-06-30
}

\section{Summary}

The distribution, life history and larva of Eopsis beaumonti Benson 1959 are briefly described. The larva is extremely adapted to endophagous life. It is monophagous on Bistorta major and is unique in having large terminal spiracles on the subanal plate of the tenth abdominal segment.

\section{Key words}

distribution, larva, food plant, adaptation

\section{Zusammenfassung}

Verbreitung, Bionomie und Larven von Eopsis beaumont BENson 1959 werden kurz beschrieben. Die Larve ist extrem an eine endophage Lebensweise monophag in Bistorta major angepasst. Einzigartig sind die großen terminalen Atemöffnungen auf der Subanalplatte des zehnten Abdominalsegments.

This species was first found in June 1959 by Dr. J. de Beaumont in the Swiss Jura, Vaud, Les Pleiades $(1200 \mathrm{~m})$ and described in the same year by BENSON (1959) as a member of the subfamily Tenthredininae, because vein $\mathrm{Sc}+\mathrm{R}$ in the forewing is slightly curved apically and because $\mathrm{M}$ joins $\mathrm{Sc}+\mathrm{R}$ at a distance from intersection of $\mathrm{Rs}+\mathrm{M}$ with $\mathrm{Sc}+\mathrm{R}$. The first character is typical for Tenthredininae, but in Eopsis is rather variable, this part of $\mathrm{Sc}+\mathrm{R}$ being slightly curved to nearly straight. TAEger (1986) gave a detailed redescription, and transferred Eopsis to the tribe Allantini of the subfamily Allantinae. LACOURT (1999) placed it in his catalogue in a tribe Eopsini, but notes in the page of Errata that Eopsini should read Allantini. Two years later (LAcourt 2001) he listed it once more as a member of the Allantini. Nevertheless, the endophagous development and unusual morphology of the larva seem to support its placement in a separate tribe. It is noteworthy that though this species is quite conspicuous and characteristic in colour, no specimens collected before the middle of the 20th century have been detected in any collections.

Since its description E. beaumonti has been recorded from the following countries:

France: Jura, Lamoura 1200 m; Hautes-Alpes; Savoie; Loire; Haute-Loire 1150 m; Massif Central, 850-1200 m, Puy-de-Dôme (Lacourt, 1976, 1985, 2001 and NobleCOURT, 2006). Czech Republic: Giant Mts. (Beneš, 1984, 2012, 2013); Jizerské hory Mts. (MACEK 2009). Germany: Harz (TAEger 1986); Bavaria (Blank et al. 2001); Hesse (LöHr 2014). Slovakia: High Tatra Mts., Javorina (RoLler 1999); Zadná Javorová dolina (valley) up to $1600 \mathrm{~m}$ (Roller \& Haris 2008). Belgium: No exact locality given (Mol 2002). Poland: Giant Mts. (Beneš 2012, 2013). Russia: Moscow Region, based on the synonymy with Monsoma mosquense Zhelochovtsev, 1981 by TAeger (1986). 
In the Giant Mountains (Krkonoše in Czech, Karkonosze in Polish, Riesengebirge in German) Eopsis beaumonti had been found in the 1980's quite commonly in all places with stands of Bistorta major (BENEš 2013). In May 1982 this species seemed to be dominant on meadows at Harrachov-Rýžoviště, and was more common than such ubiquistic species as Dolerus aeneus Hartig, 1837 or Pachyprotasis rapae (Linnaeus, 1767). Larvae were found in the stems of Bistorta major, at all places where the plant occurred, from the lower montane zone (Harrachov, $700 \mathrm{~m}$ ) to the alpine zone high above the upper tree line (Kaplička, saddle between Luční and Studniční Mts, $1510 \mathrm{~m})$. New records of larvae: Slovakia, The Belanské Tatry Mts., Zadné Medodoly, 1200 m, Predné Medodoly, former Kežmarská chata (1600 m); The High Tatra Mts., Skalnaté pleso (lake), $1450 \mathrm{~m}$. While in the 1980 's plenty of larvae were found in Zadné Medodoly, by 2007 the stand of Bistorta had been overgrown by spruces and only three larvae could be found.

Unlike other representatives of the subfamily Allantinae, the larvae of Eopsis are endophagous. They bore in the stems of Bistorta major and are conspicuously adapted to endophagous life. Oviposition takes place into an ochrea at the base of an internode. The 1st instar larva bores immediately after eclosion into the stem above the node and starts to feed upwards towards the medulla. Oviposition apparently continues at the same locality for a longer time, as up to three larvae of different instars were found in the same stem, from the eldest one (3rd instar) in the basal internode (Fig. 2), to a freshly hatched larva in the terminal one. Data on Rumex as a host plant (BENEš, 1984, Liston, 1997) are apparently erroneous, as a female oviposited in the laboratory into Rumex alpinus but the larvae developed only for a short while, then perished. Furthermore, when the larvae were transferred in the laboratory from Bistorta to Rumex, they admittedly started to bore into the pith, but died soon afterwards. They are apparently monophagous, as no larvae were found on Bistorta vivipara (in the Belanské Tatry Mts.) close to the stands of infested Bistorta major.

Infested plants are usually easily recognized by a fading, rather yellowish than pink coloration of the flower spike, which is usually also smaller. The larvae have four feeding instars. Nothing definite is known about formation of a cocoon, but it is probable that the mature larvae bore into dry stems or bark to pupate, in the same way as most other Allantinae.

\section{Morphological adaptations of the larva.}

Morphology of the mature larva (Fig. 1). Head subglobose, yellowish brown, without visible setae (x100), thoracic legs normal, tarsal claws with basal lobe. Integument of the body smooth, soft and whitish without visible setae, pseudopods on abdominal segments 2-7, indistinct ones on segment 8 . Abdominal segments $1-7$ with six annulets, segments 8 and 9 reduced. Subanal prolegs narrow and distinctly tapering, directed backwards. Suranal plate (Fig. 3) flat, posteriorly subtruncate, laterally and posterodorsally with slightly brownish pigmented warts.

Some characters of Eopsis are shared with other endophagous larvae, such as the nearly glabrous integument without visible setae and the feebly developed prolegs. On the other hand, Eopsis possesses a conspicuous adaptation of the tracheal system that has not been found in any other sawfly larva. While in other sawfly larvae the spiracles are on thoracic segments 1 (and often also 3), and abdominal segments 1-8, the prothoracic ones being the biggest, in Eopsis the spiracles are present also on segment 10. A terminal pair of spiracles is located laterally in the basal part of the suranal plate and these spiracles are about twice as long as the prothoracic and abdominal ones. Further, the tracheal trunk is here also much wider than in the thoracic equivalent. The tergum of the anal segment is flat, more strongly sclerotized than other parts of the body, laterally and posteriorly with brownish warts, and is used as a cork to close an opening in the stem. In the 1st and 2nd instar larvae, the prolegs are well developed and the fine chaetotaxy of the trunk is visible (against a black background). Pale setae on posterior edge of subanal plate dense and about as long as antennae; setae on abdominal segments sparse.

\section{References}

Beneš, K. 1984: Record from the Giant Mts. - Symphytos 2: 8 .

Beneš, K. 2012: Poznámky k bionomii Eopsis beaumonti BENSON 1959 (Tenthredinidae), pp. 5-6. [Notes to the life history of Eopsis beaumonti BeNsON 1959 (Tenthredinidae)]. - In: BEZDĚČKA, P. \& BEZDĚČKovÁ, K. (eds.): Blanokřídlív českých zemích a na Slovensku 8. [Hymenoptera in the Czech countries and Slovakia 8] Chaloupky, 1.-3. června 2012, sborník abstraktů $\mathrm{z}$ konference [review of abstracts from the conference] MJV Jihlava. 37 pp. (in Czech).

Beneš, K. 2013: Širopasí blanokřídlí (Hymenoptera, Symphyta) české části Krkonoš. [Hymenoptera Symphyta of the Czech part of the Krkonoše Mountains]. - Opera Corcontica, Vrchlabí 50: 35-80 (in Czech, with English summary).

Benson, R. B. 1959: Tribes of the Tenthredininae and a new European genus (Hymenoptera: Tenthredinidae). - Proceedings of the Royal. Entomological Society, (B), London 28: 121-127.

Blank, S. M.; Deters, S.; Drees, M.; Jänicke, M.; Jansen, E.; Kraus, M.; Liston, A. D.; Ritzau, C. \& Taeger, A. 2001: Symphyta. - In: Dathe, H. H.; TAeger, A. \& Blank, S. M. (Hrsg.): Verzeichnis der Hautflügler Deutschlands (Fauna Germanica 4). Entomologische Nachrichten und Berichte, Dresden Beiheft 7: 8-27. 
LaCOURT, J. 1976: Notes sur les Hyménoptères Tenthredoïdes. Espéces rares ou nouvelles pour la France. - L'Entomologiste 32 (4-5): 188-196.

LACOURT, J. 1985: Notes sur les hyménoptères tenthrédoïdes: espéces rares ou nouvelles pour la France (3e note) (Hymen. Symphyta). - Entomologia gallica 1 (4): 307-313.

LACOURT, J. 1999: Répertoire des Tenthredinidae ouestpaléarctiques (Hymenoptera, Symphyta). - Mémoires de la Société Entomologique de France 3, Paris: $432 \mathrm{pp}$.

LACOURT, J. 2001: Note faunistique concernant quelques espèces de tethredinidae rares ou nouvelles pour la France (Hymenoptera, Symphyta). - Bulletin mensuel de la Société Linnéenne de Lyon 70 (9): 217-233.

Liston, A. D. 1997: Host plant list for European and North African Megalodontoidea and Tenthredinoidea (Hym.). - Sawfly News, Daibersdorf 1 (3): 30-58.

LöHR, P.-W. 2014: Der Brethsfeldteich - Beobachtungen und Untersuchungen an einem Kleingewässer im Vorderen Vogelsberg. - Beiträge zur Naturkunde in Osthessen 51: 35-62.

MACEK, J. 2009: Symphyta (Hymenoptera) of the Jizerské hory Mts. and Frýdlant region (northern Bohemia, Czech Republic). - Sborník Severočeského Muzea, Př́rodní Vědy, Liberec 27: 199-237.

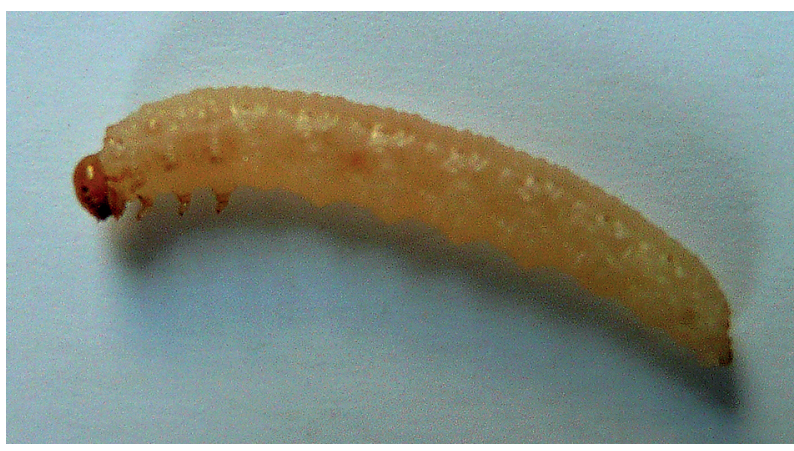

Fig. 1: Mature larva of Eopsis beaumonti.

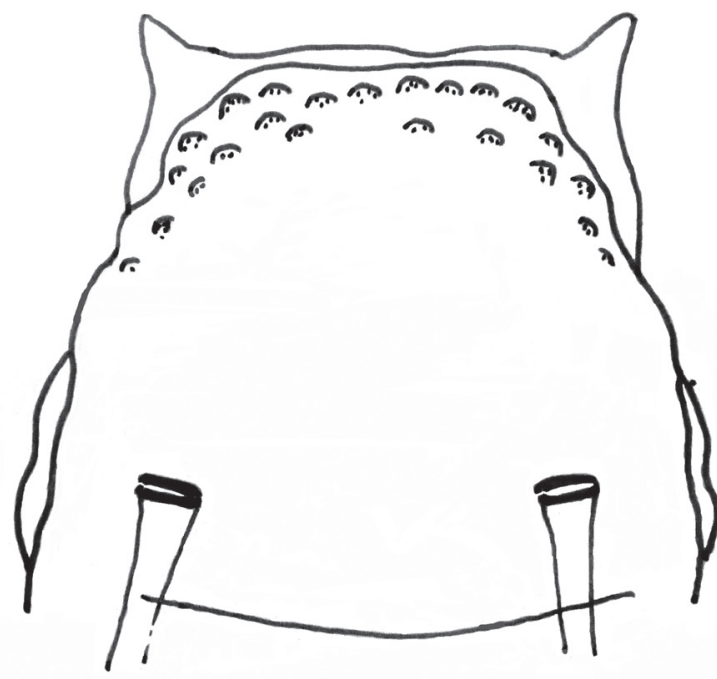

Fig. 3: Suranal plate in dorsal aspect.
Mol, A. 2002: Overzicht van de families en genera van de Nederlandse bladwespen (Hymenoptera: Symphyta). II. - Nieuwsbrief sectie Hymenoptera van de nederlandse. Entomologische Vereinigung nr. 16 (November 2002): 44-60 (in Dutch).

Noblecourt, T. 2006: Données faunistiques sur quelques Hyménoptères Symphytes (Siricidae, Pamphiliidae, Xyelidae, Tenthredinidae) rares ou nouveaux pour la France (deuxiéme note). pp.333-340. - In: Blank, S. M.; Schmidt, S. \& TAeger, A. (eds.): Recent Sawfly Research, Synthesis and Prospects. Goecke a Evers, Keltern.

Roller, L. 1999: Společenstvá širopásych (Hymenoptera, Symphyta) vybraných zoogeografických regiónov Slovenska. - PhD. thesis, Ústav zoológie, SAV Bratislava: $180 \mathrm{pp}$.

Roller, L. \& HARIS, A. 2008: Sawflies of the Carpathian Basin, History and Current Reearch. - Natura Somogyiensis 11, Kaposvár 2008: 259 pp.

TAeger, A. 1986: Beitrag zur Taxonomie und Verbreitung paläarktischer Allantinae (Hymenoptera, Symphyta). - Beiträge zur Entomologie, Berlin 36: 107-118.

Taeger, A. \& Blank, S. M. 2011: ECatSym - Electronic World Catalog of Symphyta (Insecta, Hymenoptera). - Program version 3, data version 38. Digital Entomological Information, Müncheberg.

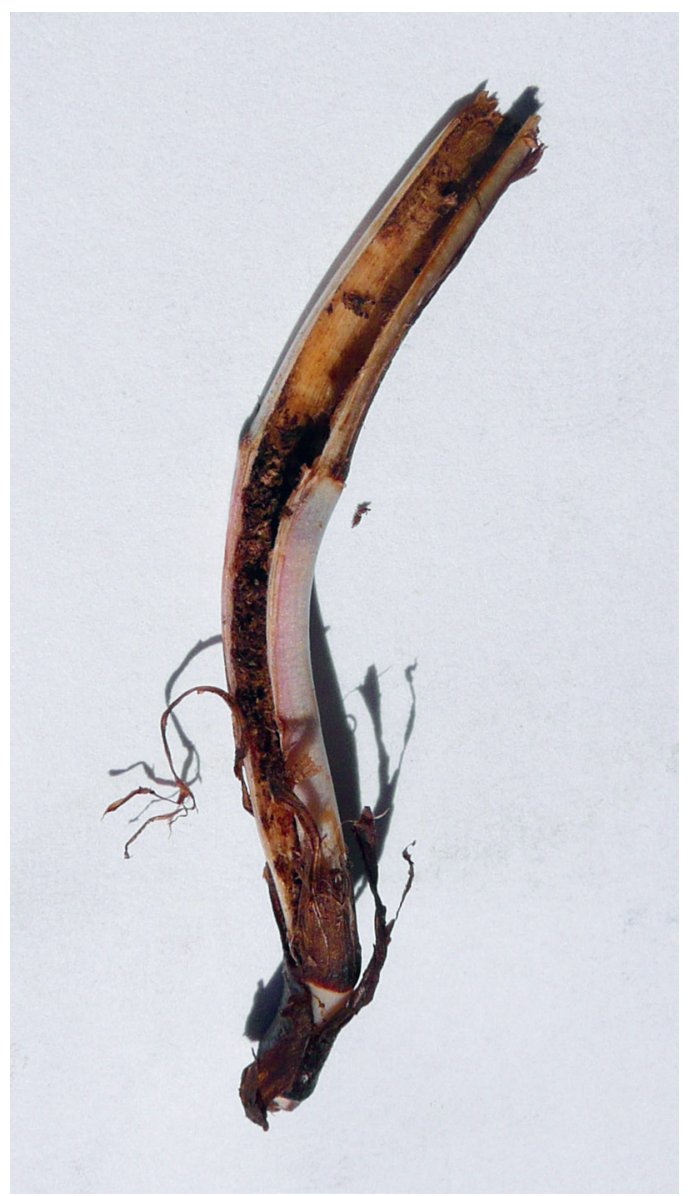

Fig. 2: Dissected basal part of stem of Bistorta major infested by larva of Eopsis beaumonti. 